\title{
S URRENDER
}

(BUT DON'T GIVE YOURSELF AWAY) 
, urres 


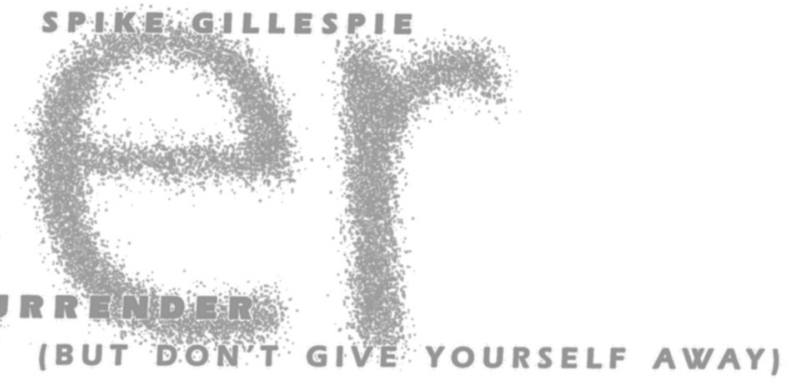

OLDCARS,

FOUND HOPE,

AND OTHER

CHEAP TRICKS

4 UNIVERSITY OF TEXAS PRESS, AUSTIN 
COPYRIGHT ○ 2003 BY THE UNIVERSITY OF TEXAS PRESS

All rights reserved

Printed in the United States of America

First edition, 2003

Requests for permission to reproduce material from this work should be sent to Permissions, University of Texas Press, P.O. Box 7819, Austin, TX 78713-7819.

( The paper used in this book meets the minimum requirements of ANSI/NISO Z39.48-1992 (R1997) (Permanence of Paper).

LIBRARY OF CONGRESS CATALOGING-IN-PUBLICATION DATA

Gillespie, Spike.

Surrender (but don't give yourself away) : old cars, found hope, and other cheap tricks / by Spike Gillespie.

p. $\quad \mathrm{cm}$.

ISBN: 978-0-292-71945-3

I. Title.

PN4874.G386 A25 2003

$814^{\prime} .6-\mathrm{dc} 21$

2003010208 
This book is dedicated to

Claudia Kolker

and

Michael Stravato

and

Nancy Brzuska

for years of ongoing faith

and hope and encouragement.

And,

as always,

to

Henry Mowgli Gillespie,

my Love,

for his unconditional everything

and his extraordinary patience. 
THIS PAGE INTENTIONALLY LEFT BLANK 
We're all allright.

"Surrender," Cheap Trick at Budokan 
THIS PAGE INTENTIONALLY LEFT BLANK 